\title{
The Impact of Using Authentic Videos on Prosodic Ability among Foreign Language Learners
}

\author{
Ehsan Namaziandost \\ PhD Student, Department of English, Faculty of Humanities, Shahrekord Branch, \\ Islamic Azad University, Iran, e.namazi75@yahoo.com
}

\section{Fariba Rahimi Esfahani}

Asst. Prof., Corresonding author, Department of English, Faculty of Humanities, Shahrekord Branch, Islamic Azad University, Iran, rahimi_fariba@yahoo.com

\section{Arash Hashemifarnia}

PhD Student, Department of English, Faculty of Humanities, Shahrekord Branch, Islamic Azad University, Iran, sadi6675@gmail.com

This study examined the effect of using authentic videos on Iranian EFL learners' prosodic ability. To this end, the researcher selected 40 Iranian intermediate students and randomly assigned them in two equal groups; one experimental group and one control group. A pre-test was administered to both groups to make sure that they are homogeneous. Then, the control group was taught prosodic aspects of language using a traditional approach while the experimental group was taught through using authentic videos. The whole treatment lasted 12 sessions of 70 minutes. At the end of the study a post-test was administrated and the scores obtained from two groups were compared using paired samples and independent samples t-tests. The findings revealed that the experimental group significantly outperformed the control group $(\mathrm{p}<.05)$ on the post-test. In other words, teaching through authentic videos showed to have a significant impact on improving learners' prosodic ability. Implications of the study suggest that using authentic videos could be more effective than other techniques in teaching prosodic aspects of language to intermediate EFL learners.

Keywords: authentic videos, prosodic ability, intonation, pronunciation, stress, pause, juncture, rhyme, prosodic aspects of language.

\section{INTRODUCTION}

Over the last two decades especially from the second half of the 1990s up to the present time, there has been a considerable increase in applied linguistic research studies on the teaching and learning of pronunciation. They are presently focusing on the significance

Citation: Namaziandost, E., Esfahani, F. R., \& Hashemifarnia, A. (2018). The Impact of Using Authentic Videos on Prosodic Ability among Foreign Language Learners. International Journal of Instruction, 11(4), 375-390. https://doi.org/10.12973/iji.2018.11424a 
of pronunciation, not only in encouraging native-like accents, but more predominantly for communication. Hence, going beyond individual sounds and phonemes to sentencelevel stress and intonation has turned into an absolute necessity in language teaching (Hardisom, 2004).

The present study in the scope of computer assisted language learning (CALL) concentrates on a further efficient intermixture of computer innovation into the teaching and learning process and on including the prosodic factor into the process of language learning. The major objective is, hence, to combine both segmental and supra segmental dimensions, particularly in discourse and communication, and to propose an intricate structure for pursuing foreign language pronunciation. Because of its intrinsic intricacy, deficiency of information about sufficient prosody processing both for linguistic and technological necessities, additionally absence of consideration to the troubles in their attainment, difficulties of intonation and other prosodic phenomena such as rhythm and voice quality were overlooked in language teaching for a long time (Hirata, 2004). When a student can generate individual sound sectors which are very identical to those created by the instructor, they may still appear 'wrong' because of general voice quality. Moreover, acoustic characteristics applied in the discernment of intonation should be considered. For instance, the software could (a) educate learners to evaluate the steepness of their falling or rising pitch motion to that of the native speaker, and/or (b) give a quantitative estimation of the real pitch inclines of both the native speaker and the student. An effectual consequence of this type needs usage of some sorts of pitch stylization and normalization (Peter, 2002).

Therefore, contrastive analysis is deliberately utilized by linguists to recognize potential pronunciation challenges of non-native speakers of a language. The Contrastive Analysis Hypothesis proposes that through differentiating the highlights of two languages, the troubles that a language learner might face can be expected (Crystal, 2003). Characteristics of numerous languages were indexed by linguists, but it was impossible to systematically foretell which zones of English would be troublesome for speakers of special native languages. A less predictive version of the hypothesis stressed on cross-linguistic impact, which professes that previous language knowledge have an effect on the way of learning a language, but these experiences do not constantly have predictive value (Brown, 2000). Based on this study, it is possible for linguists to expand lists of sounds that are problematical for native speakers of special languages in learning English. For instance, Asian languages speakers may have problem generating $/ \mathrm{p} /$ and $/ \mathrm{r} /$ sounds; speakers of Spanish may have difficulty distinguishing between and producing $/ \mathrm{sh} /$ and $/ \mathrm{ch} /$ sounds. These lists for particular language experiences are now characterized in pronunciation texts, like Sounds Right (Braithwaite, 2008), and pronunciation software plans, such as American Speech Sounds (Hiser \& Kopecky, 2009). Instructors can likewise learn an extraordinary deal by watching the English students in their classes as they speak with each other. Through considering places where communication breaks down and characterizing the pronunciation specifications that create miscommunication to happen, teachers are able to recognize pronunciation traits that they must emphasize in class. Hardison (2004) believed that teachers should 
note the students' pronunciation mistakes and difficulties when they give presentation or when they work together in pairs or groups.

Prosodic pronunciation difficulties are universal. Various acoustic or even grammatical instruments are vital to generate the identical prosodic findings in diverse languages, therefore producing interaction troubles for non-native speakers of a language. For instance, Japanese speakers of English put same stress on every syllable, have difficulties with schwa, embed vowels, have problems in comprehending the relation among the place of stress and meaning, and have low flat pitch (males) (Eskenazi, 1999). Notably, viewpoints of speech intonation that have developed by the starting of 2000 reverberate the present perspective that intonation supplies some measure of abundance and repetition to linguistically- oriented messages, but additionally provides extra clues to represent the complete meaning that speakers desire to convey. Numerous analysts would concur that sentence prosody is distinguished excessively by interactive purposes or capacities than by formal tenets, as in conventional and structural or phonological methodologies (Hardison, 2004).

Furthermore, Tarone (2005) claims, "It is an incontestable reality that intonation has a momentous role in the declaration of sentimentality and viewpoints. Therefore the task of linguist is not specifying whether intonation demonstrate a speaker's internal moods or not but rather how much of this expression is actually linguistic" and whether international characteristics that state feelings are worldwide or only particular to language (pp. 173-174). Considering carefully the viewpoints of numerous linguists, there are various degrees and outcomes of exchange. Unavoidably, exchange of sounds and/or intonation from LI to L2 bring about a "foreign accent," which necessitates not barricade comprehension. Seriously, however, would be issues of understanding or misapprehension that emerge from the supposed "negative transfer." Gibson (2008, adduced in Varasarin, 2009) proposed that whereas transfer at the level of the phoneme is "self-constraining", transfer at the prosodic level is more earnest in light of the fact that it is "congested".

Generally, as these results propose, more emphasis should be put on supra segmental features than on the segmental phonemes, or that they should be taken into account equally. This enables students to reach a most closely proximate near-native accent and, more significantly, eschew pragmatic and sociolinguistic aspects of misapprehensions because of transfer from LI. Though, second and foreign language classes, there are convincing testimonies for improving the present tendency toward communicative proficiency. To become more adept communicators, language learners ought to be instructed how to utilize and comprehend discourse intonation.

Long experience of instructing English as a foreign language has disclosed it for researchers that Iranian EFL learners have difficulties in pronunciation. They speak English with something near to pension pronunciation. This might be because of the fact that foreign language teachers and instructors are usually seen as models. They themselves have difficulties in pronunciation (Khaghaninejad \& Maleki, 2015). Consequently, this imperfection might prompt issues in interaction, since the musicality of oral messages create a vital role in elucidating and choosing the precise predestinated 
meaning which is in the speakers' brain and heart. Differently, a type of misconception might happen in communication, which might result to misunderstanding, conflicts, antipathy, animosity and warfare. Accordingly, to remove the gap, EFL educators must instruct languages utilizing native forms of language in various situations based on electronic innovation. Furthermore, although Iranian students have about eight years of learning English before they enter the university, they still appear having difficulties in distinguishing specified sounds, rhyme, and the non-segmental aspects of speech, for example, intonation, stress, pause, and juncture. The problem is so serious and drastic that it repeatedly has effects on foreign language teaching and learning. Foreign language experts, particularly foreign language curriculum designers and methods should try to find the best way to develop the prosodic ability of the participants in foreign language classes. For instance, a second-year college or high school student in an English class may say (able) instead of (apple). Here, not only students should be blamed for inadvertency, but also the teacher might have participated in the problem because he/she is the model for the students. This example might help the researcher to conclude that some of foreign language learners' mistakes are due to as (Corder, 1983, p. 32) expressed, "neither learners have been done enough endeavours nor the teachers give sufficient explanation and practice". The teacher should know about the troubles and difficulties his/her students confront and consider.

Moreover, foreign language learning is not a simple work. It requires arduous tasks and workout, particularly in the fields which are not quite the same as the student's native language. Acquiring accurate pronunciation pertains extremely on the teacher, since he/she teaches the learners to listen and generate the new language sounds. EFL teachers should pay specific attention to those unfavourable speech habits that learners obtain in elementary and even high school. English language students usually study the rules of phonetics in university, however they carry on to pronounce English words inaccurately and spell them similar to the way they pronounce them. Accordingly, foreign language learners' competence should be extremely considered through utilizing videos to educate recorded models by native speakers. These suppositions lead the researcher to form the study hypothesis as "there is a statistically significant difference between the mean scores of students' prosodic ability before and after being exposed to authentic videos.

To sum up, this study aims to investigate the role of authentic videos on improving the Iranian learners' prosodic ability studying in English since language prosody not only enhances their communicative competence but their proficiency as well.

\section{Objectives and Significance of the Study}

The pronunciation itself is an intricate concept which consist of sounds, syllables, and intonation, and each of these elements require specific care since pronunciation is as momentous to the learner as culture, grammar, vocabulary, and the other parts of language. The purpose of this study is to help the students speak understandably via accurate pronunciation of the language. Regarding second language learning, teachers and students require more appreciable speech factors to work with. As a result, the researcher endeavours to find out the phonetic relations of language musicality, or "singing" in the pronunciation of second language learners with the aid of authentic 
videos. Therefore, this study aims at measuring the impact of authentic videos on the EFL learners' suprasegmental ability. This research focuses primarily on an essential issue in teaching second or foreign language, because the mechanics of speaking are rarely taken into account in traditional EFL classes. Furthermore, it stresses the role of authentic videos in the learning of the prosodic ability of language.

The importance of this study can be specified in the following areas:

- This study is one of the rare researches carried out about the impact of authentic videos on EFL students' prosodic ability.

- The importance of this study lies in the fact that it can help English language teachers, supervisors, examiners, textbooks designers and curriculum developers to be aware of the essential role of authentic videos in teaching and learning a foreign language since language is an ear and a tongue.

- The study would be useful and beneficial for the ministries of education in the nonnative countries of English, particularly for textbook writers to include English language textbooks with CDs that contain recordings of native speakers of English as samples for teaching the pronunciation of speech sounds, intonation, stress, pause, and juncture.

\section{Research Question and Hypothesis}

RQ. Do authentic videos have any significant effect on Iranian intermediate EFL learners' prosodic ability?

The study assumed that:

H0. Authentic videos do not have any significant effect on Iranian intermediate EFL learners' prosodic ability.

\section{REVIEW OF THE LITERATURE}

\section{Studies on the Significance of Prosody to Communicate Meaning}

In 1987, James and Leather worked on prosodic part of intonation, which is an essentially larger ratio than would have been appeared in former decades. Another study by Dechert and Raupach (1987) dealt with the prosodic aspects of "proceduralized speech" and proposed that prosody extremely help process L2 speech. Cruz-Ferreira (1987) in a study focused on conceptual processing of second language; she trusted that misunderstandings as a result of imperfect understanding of intonation mostly undistinguishable and uncorrected. The findings of her empirical research of non-native prosodic ability with English and Portuguese speakers demonstrated that listeners utilize different tactics to construe prosodic meaning. Furthermore, Morley (1992) argued the main impacts on the altering patterns of pronunciation training in ESL in the U. S. and mentioned two vital catalysts in causing the change: (1) the instantaneous requirements of ESL students whose pronunciation problems may lead to professional or social detriments, and (2) a number of appearing intents that look to reverberate an pivotal credence system shared by numerous new pronunciation plans. Her list of principles contained the increasing tendency towards communicative methodologies. Late researches on discourse, both in theoretical linguistics and second or foreign language pedagogy, have concentrated on elucidating principles for the understanding and generation of coherent verbal interplay. The contributing components of coherent 
association are not merely the principles of grammaticality in any given language, but also contain the pragmatic or functional rules that lead the utilization of utterances in spoken discourse. More significantly, Pennington and Ellis (2000) wrote about two empirical researches of Cantonese speakers' memory for English sentences with prosodic clues and discovered that their memory was totally poor, both when the contrastive concentration was implied in the empirical task and when it was the unequivocal center of regard. Learners' performance was developed considerably when their care had been obviously coordinated to intonation, but only for sentences in which prosody implied a marked informational concentration. To sum up, in the researches of the 1980 s to $2010 \mathrm{~s}$, the theoretical argumentations for looking language as a communicative phenomenon that potentially contains intonation - a process in which information and purpose are both transferred and received - were presented. The reasonable usages were that models of both communicative competence and proficiency models should utilize the intonation in governing discourse. The proficiency-based teachers in the classroom must endeavour to develop communicative language proficiency by obviously informing the learners that intonation plays a fundamental role in prosperous and meaningful communication, and start to merge the instructing of intonation into the second and foreign language programs.

\section{Studies on the Impact of Authentic Videos on Prosodic Components of Language}

Abdullah (2011) analysed the effect of two self-evaluation instruments, namely videorecording and self-reflection papers, on the learners' communicative (verbal) and paralinguistic (non-verbal) performance in a communication and presentation skills period at Cairo University Faculty of Engineering. At the end of the term an online survey was carried out to examine students' understanding on how the assessment instruments had effect on their presentation performance all over the course. The consequences of the survey indicated a desirable propensity towards watching the videos and writing reflectance papers. Students thoroughly accepted that watching their videorecordings has had a positive impact on their future presentation performance. Abdolmanafi-Rokni (2013) investigated the usefulness of listening to audio-stories on developing EFL learners' pronunciation. Two intact classes at Novin institute in Gorgan, Iran, were randomly chosen and divided into two various groups namely, experimental and control. The experimental group got teaching via listening to audiostories as a technique to advance pronunciation for eight sessions, while the control group received a placebo. The findings demonstrated that there was a significant difference between the means of the experimental group and its control counterpart and a development was seen in the learners' general pronunciation ability in the post-test. In another study, EbruAtak (2014) examined the effectiveness of using videos on the improving English stress and intonation of first grade EFL learners in an ELT Department at a public university in Turkey. Forty-four EFL learners took part in the research voluntarily. Twenty-four students, assigned as the experimental group, were presented a list of videos and an online tutoring schedule and pertinent homework as complementarity to a 3-hour listening and pronunciation course every week. The results of the research showed that videos were extremely beneficial in developing the EFL learners' ability to generate and understand various stress and intonation patterns in 
words, phrases and sentences as compared to the online tutoring programs. Recently, AlDomi (2017) examined the impact of utilizing authentic videos on teaching center and community service students' prosodic ability and motivation. The population of the study comprised of 50 male students randomly selected from Training Center and Community Service at King Saud University, Saudi Arabia, and assigned to experimental $(n=25)$ and control groups $(n=25)$. The researcher taught both groups purposely utilizing contrasting instructional methods; the first group were only presented to textbook content, excluding all visual aids all over the process; while the second group was exposed to authentic videos. Finally the results indicated that the experimental group's students reinforced their prosodic ability and motivation. In sum, applying authentic videos in teaching and learning English has a positive impact on the mentioned prosodic ability and motivation scopes.

All the studies mentioned above revealed that use of technology in general and authentic videos in particular play a fundamental role in learning the mechanics of speaking. The current research is identical to the aforesaid studies in the overall purpose. However, what distinguished this study from the other former studies is that it carefully scrutinized the impact of using authentic videos on EFL learners' prosodic ability.

\section{METHOD}

The sample of the study was comprised of 38 English learners. They had been studying English for four years in a private language institutes, Ahvaz, Iran; and they ranged in age from 15 to 20. The learners took the Oxford Placement Test (OPT) in order to make sure they were homogeneous. It is worth noting that only male students were included as the target respondents. Sixty students who scored the intermediate level (i.e., 28-47) based on the Oxford Placement Test were selected as the research sample. Then they were divided into two equal groups. Through non-random convenience sampling method, two groups were selected as the experimental group $(\mathrm{n}=20)$ and control group $(n=18)$.

\section{Procedures of the Study}

The principal steps applied to fulfil the goals and confirm the supposition of the research are as follow:

- $\quad$ Recognizing the prosodic features of language to be investigated, containing pause, juncture, intonation, pronunciation, and stress.

- Designing a scale of scores in the prosodic components of language, ranging from 0 to 100 .

- $\quad$ Scores were dispersed reasonably between the prosodic aspects of language.

- Oxford Quick Placement Test was administered to realize the participants' proficiency level

- A pretest was carried out to detect the factual level of both groups before being subjected to the new experience of instructing.

- $\quad$ Then, the control group was taught traditionally, while the experimental group was taught through videos. A famous and popular series was chosen to carry out in the 
study. A main reason was that in series ordinarily the identical characters play in numerous episodes. So, learners can make emotional connectivity with the characters and that makes it simpler and less stressful for them to watch the material. Another reason to utilize series is the general belief on using an up-to-date material so that the content of material would not be out-of-dated. Since the language utilized in old movies may not be utilizable in modern English, in order to ensure of the suitability of the material applied, four raters rated the movie to affirm that the dialogues in the chosen series were of standard English and likewise the content of the material was culturally proper for Iranian adult learners. Twelve sessions later, a posttest was executed to understand if any metamorphosis happened and in favor of either group.

- Both the pretest and the posttest were in the form of oral interviews accomplished by well -experienced experts of English.

- The interviewers wrote obvious and voluminous reports about every learner's execution in the suprasegmental part of language. Their reports were amalgamated with scores that ranged from 0 to 100 . The total score of each tester in the prosodic features of language was out of one hundred.

- To prevent from subjectivity, each examiner was responsible for appraising and evaluating one prosodic dimension of language.

- $\quad$ Finally, the whole score was computed to be out of 100 for each student.

\section{Data Analysis Procedures}

Data collected through the pre and post-tests were analysed through SPSS software, version 25. Independent and Paired samples $T$ tests were utilized to distinguish the prosodic parts of language that the students improved excessively because of utilizing authentic videos.

\section{Validation of the Tools}

Before applying any instrument of examination, it is fundamental to ensure that it contains all the prerequisites of a suitable instrument. i.e., it ought to be valid, reliable and with a plausible amount of hardness. To ensure that the test meets all the previously mentioned criteria, the following stages should be taken into account: To make sure about face validity of the test, three proficient experts who were famous and praiseworthy for their longsome experience in the field of TEFL, scrutinized it carefully. They presented some suggestions on the items regarding the dispensation of the scores between the prosodic aspects of language.

\section{Reliability of the Test}

Test-retest method is one of the suitable techniques that can be utilized to understand the test reliability (Storm, 1969). This method was applied in this study. Ten students were chosen randomly from another institution. Two weeks later, recordings of their oral performance were evaluated by the proficient raters. Through applying Pearson's formula, the pilot execution of the test demonstrated that, the correlation coefficient among learners' ranks on both assessment occasions were computed and observed to be 94\%. Based on Pearson's formula, the reliability coefficient of a test would be satisfactory if it is not under 0.50 (Stempell, 1981). Therefore the test can be characterized as being exceedingly reliable. 


\section{Instruments of the Study}

During the term, the researcher designed a scale for the study in prosody. It ranged from 0 to 100 . Scores were dispensed reasonably between the prosodic parts of language; 30 scores for intonation, 30 for pronunciation, 20 for stress, 10 for pause, and 10 for juncture. The evaluation of students' general prosodic ability was constructed based on the scale devised by the researchers. Recordings of students' oral execution in both groups were made at the outset of the term. These recordings were assessed by four proficient experts of English who are well-known in TEFL. Each learner was assessed individually based on the scale of judgment. The total score was out of 100. The examiners compose fully detailed reports about the real supra segmental ability of each learner in both groups before beginning the experiment. These reports were followed by scores as scores are more objective and reliable than words. The group of examiners comprise of four specialists; one of these experts was in charge of assessing leaners' pronunciation of speech sounds, while the second had obligation of assessing learners' intonation. The third was accountable for appraising word and sentence stress. The fourth was in charge of for evaluating students' utilization of pause and juncture. After interviewing every student autonomously, scores were given by the group of analysts. Then, the total score was computed to be out of 100 for each student in both groups.

\section{FINDINGS}

Independent Samples T-test and Paired Samples T-tests were used to analyse the data; the results are reported in the following tables.

Table 1

The experimental group's performance on pre-test

\begin{tabular}{llllll}
\hline $\begin{array}{l}\text { Student's } \\
\text { number }\end{array}$ & $\begin{array}{l}\text { Pronunciation } \\
\text { out of } 30\end{array}$ & $\begin{array}{l}\text { Intonation out } \\
\text { of } 30\end{array}$ & $\begin{array}{l}\text { Stress out of } \\
20\end{array}$ & $\begin{array}{l}\text { Pause and } \\
\text { juncture out of } 20\end{array}$ & $\begin{array}{l}\text { Total out of } \\
100\end{array}$ \\
\hline 1 & 15 & 16 & 12 & 12 & 55 \\
\hline 2 & 17 & 14 & 11 & 9 & 51 \\
\hline 3 & 13 & 13 & 10 & 11 & 47 \\
\hline 4 & 13 & 11 & 14 & 10 & 48 \\
\hline 5 & 17 & 17 & 12 & 14 & 60 \\
\hline 6 & 20 & 19 & 14 & 12 & 65 \\
\hline 7 & 17 & 19 & 13 & 15 & 64 \\
\hline 8 & 16 & 17 & 8 & 8 & 49 \\
\hline 9 & 20 & 20 & 14 & 13 & 67 \\
\hline 10 & 21 & 15 & 14 & 10 & 60 \\
\hline 11 & 15 & 14 & 10 & 18 & 57 \\
\hline 12 & 13 & 17 & 9 & 10 & 63 \\
\hline 13 & 17 & 17 & 13 & 16 & 59 \\
\hline 14 & 18 & 17 & 12 & 12 & 61 \\
\hline 15 & 18 & 18 & 13 & 12 & 68 \\
\hline 16 & 21 & 19 & 13 & 15 & 57 \\
\hline 17 & 17 & 21 & 9 & 10 & 60 \\
\hline 18 & 16 & 17 & 13 & 14 & 60 \\
\hline 19 & 18 & 18 & 14 & 14 & 64 \\
\hline 20 & 19 & 17 & 11.85 & 12.5 & 58.2 \\
\hline Average & 17.05 & 16.8 & & & \\
\hline
\end{tabular}


Table 2

The control group's performance on pre-test

\begin{tabular}{llllll}
\hline $\begin{array}{l}\text { Student's } \\
\text { number }\end{array}$ & $\begin{array}{l}\text { Pronunciation } \\
\text { out of } 30\end{array}$ & $\begin{array}{l}\text { Intonation } \\
\text { out of } 30\end{array}$ & $\begin{array}{l}\text { Stress out } \\
\text { of } 20\end{array}$ & $\begin{array}{l}\text { Pause and juncture } \\
\text { out of } 20\end{array}$ & $\begin{array}{l}\text { Total out of } \\
100\end{array}$ \\
\hline 1 & 17 & 17 & 10 & 11 & 55 \\
\hline 2 & 18 & 15 & 12 & 8 & 53 \\
\hline 3 & 14 & 10 & 8 & 7 & 39 \\
\hline 4 & 10 & 10 & 11 & 5 & 36 \\
\hline 5 & 18 & 16 & 14 & 8 & 56 \\
\hline 6 & 21 & 21 & 15 & 14 & 71 \\
\hline 7 & 22 & 20 & 16 & 16 & 74 \\
\hline 8 & 19 & 15 & 15 & 11 & 60 \\
\hline 9 & 15 & 17 & 10 & 10 & 52 \\
\hline 10 & 11 & 13 & 8 & 5 & 37 \\
\hline 11 & 16 & 17 & 11 & 12 & 56 \\
\hline 12 & 24 & 22 & 17 & 16 & 79 \\
\hline 13 & 23 & 20 & 15 & 14 & 48 \\
\hline 14 & 14 & 16 & 10 & 8 & 62 \\
\hline 15 & 19 & 18 & 13 & 12 & 76 \\
\hline 16 & 22 & 21 & 17 & 16 & 63 \\
\hline 17 & 18 & 17 & 14 & 14 & 61 \\
\hline 18 & 18 & 18 & 13 & 12 & 74 \\
\hline 19 & 24 & 21 & 14 & 15 & 73 \\
\hline 20 & 20 & 22 & 16 & 15 & 59.85 \\
\hline Average & 18.15 & 17.3 & 12.95 & 11.45 & \\
\hline
\end{tabular}

Table 3

Descriptive statistics (Pre-tests)

\begin{tabular}{llllll}
\hline Groups & & N & Mean & Std. Deviation & Std. Error Mean \\
\hline \multirow{2}{*}{$\begin{array}{l}\text { Pre- } \\
\text { test }\end{array}$} & Experimental group & 20 & 58.2000 & 6.46936 & 1.44659 \\
\cline { 2 - 5 } & Control group & 20 & 59.8500 & 13.21194 & 2.95428 \\
\hline
\end{tabular}

Table 4

Independent samples t-Test (Pre-test)

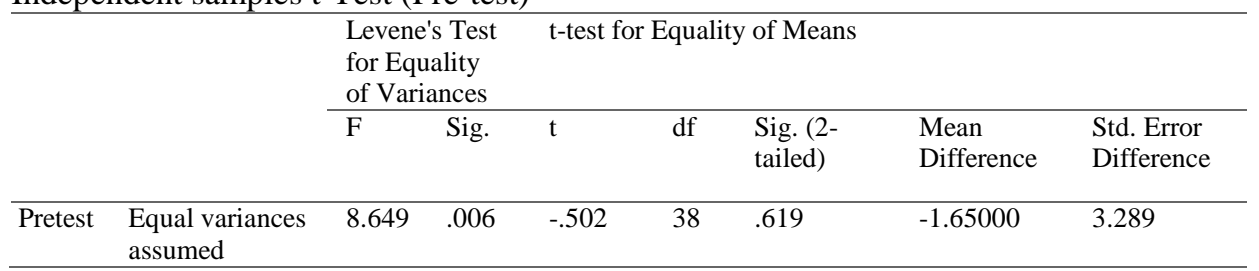

Tables 1, 2, 3 and 4 indicate that both control and experiment groups' prosodic ability before starting the treatment were approximately the same in the pre-test. Then, the experimental group was exposed to authentic videos technology to obtain the prosodic features of language efficiently and effortlessly, while the control group taught the identical material traditionally. This experiment lasted for 12 sessions. Then, the subjects of the study were re-interviewed on the similar topics and operations of language. These interviews were constructed by the same team of testers utilizing the same scale and dissemination of scores among the prosodic dimensions of language (30 
scores were considered for pronunciation of speech sounds, 30 for intonation, 20 scores for stress and 20 scores divided between pause and juncture). Table 5 and 6 demonstrate the performances of both control and experimental groups in the prosodic features of language after being instructed traditionally and through authentic videos respectively.

Table 5

The Experimental Group's performance on post-test

\begin{tabular}{llllll}
\hline $\begin{array}{l}\text { Student's } \\
\text { number }\end{array}$ & $\begin{array}{l}\text { Pronunciation } \\
\text { out of } 30\end{array}$ & $\begin{array}{l}\text { Intonation out } \\
\text { of } 30\end{array}$ & $\begin{array}{l}\text { Stress out } \\
\text { of } 20\end{array}$ & $\begin{array}{l}\text { Pause and juncture } \\
\text { out of } 20\end{array}$ & $\begin{array}{l}\text { Total out of } \\
100\end{array}$ \\
\hline 1 & 25 & 26 & 15 & 14 & 80 \\
\hline 2 & 22 & 19 & 11 & 9 & 61 \\
\hline 3 & 15 & 12 & 10 & 11 & 48 \\
\hline 4 & 16 & 11 & 10 & 10 & 47 \\
\hline 5 & 21 & 22 & 12 & 14 & 69 \\
\hline 6 & 22 & 25 & 19 & 17 & 83 \\
\hline 7 & 27 & 22 & 18 & 16 & 83 \\
\hline 8 & 20 & 24 & 17 & 17 & 78 \\
\hline 9 & 18 & 22 & 15 & 16 & 71 \\
\hline 10 & 28 & 27 & 18 & 19 & 92 \\
\hline 11 & 17 & 19 & 10 & 18 & 64 \\
\hline 12 & 15 & 18 & 11 & 10 & 54 \\
\hline 13 & 20 & 21 & 14 & 14 & 69 \\
\hline 14 & 21 & 18 & 12 & 14 & 65 \\
\hline 15 & 23 & 22 & 17 & 16 & 91 \\
\hline 16 & 28 & 26 & 19 & 18 & 68 \\
\hline 17 & 20 & 19 & 14 & 15 & 61 \\
\hline 18 & 19 & 21 & 11 & 10 & 69 \\
\hline 19 & 22 & 21 & 12 & 14 & 81 \\
\hline 20 & 25 & 22 & 17 & 17 & 70.6 \\
\hline Average & 21.2 & 20.85 & 14.1 & 14.45 & \\
\hline
\end{tabular}

Table 5 illustrates that the prosodic ability of the experimental group developed significantly due to the new experience of teaching, where the mean score of the total in the pre-test equals (mean 58.2 with $\mathrm{SD}=6.46$ ), whereas the mean was 70.6 with $=12.78$ on the post-test.

Table 6

The Control Group's performance on post-test

\begin{tabular}{llllll}
\hline $\begin{array}{l}\text { Student's } \\
\text { number }\end{array}$ & $\begin{array}{l}\text { Pronunciation } \\
\text { out of } 30\end{array}$ & $\begin{array}{l}\text { Intonation } \\
\text { out of } 30\end{array}$ & $\begin{array}{l}\text { Stress out } \\
\text { of } 20\end{array}$ & $\begin{array}{l}\text { Pause and juncture } \\
\text { out of } 20\end{array}$ & $\begin{array}{l}\text { Total out of } \\
100\end{array}$ \\
\hline 1 & 22 & 16 & 11 & 12 & 61 \\
\hline 2 & 17 & 16 & 10 & 9 & 52 \\
\hline 3 & 16 & 11 & 10 & 9 & 46 \\
\hline 4 & 9 & 10 & 10 & 7 & 36 \\
\hline 5 & 17 & 16 & 13 & 10 & 56 \\
\hline 6 & 19 & 20 & 13 & 10 & 62 \\
\hline 7 & 21 & 20 & 17 & 15 & 73 \\
\hline 8 & 21 & 16 & 16 & 13 & 66 \\
\hline 10 & 17 & 16 & 12 & 12 & 57 \\
\hline 11 & 14 & 12 & 7 & 9 & 42 \\
\hline
\end{tabular}




\begin{tabular}{llllll}
\hline 12 & 22 & 22 & 16 & 14 & 74 \\
\hline 13 & 25 & 21 & 16 & 15 & 77 \\
\hline 14 & 19 & 17 & 15 & 11 & 62 \\
\hline 15 & 18 & 19 & 16 & 15 & 68 \\
\hline 16 & 21 & 20 & 15 & 14 & 70 \\
\hline 17 & 18 & 16 & 15 & 13 & 62 \\
\hline 18 & 19 & 16 & 10 & 11 & 56 \\
\hline 19 & 24 & 20 & 16 & 15 & 75 \\
\hline 20 & 21 & 18 & 18 & 14 & 71 \\
\hline Average & 18.85 & 16.85 & 13.4 & 12 & 61.1 \\
\hline
\end{tabular}

Table 7

Descriptive statistics (Post-tests)

\begin{tabular}{llllll}
\hline Groups & & $\mathrm{N}$ & Mean & Std. Deviation & Std. Error Mean \\
\hline \multirow{2}{*}{$\begin{array}{l}\text { post- } \\
\text { test }\end{array}$} & Experimental group & 20 & 70.6000 & 12.78321 & 2.85841 \\
\cline { 2 - 6 } & Control group & 20 & 61.1000 & 11.25260 & 2.51616 \\
\hline
\end{tabular}

Table 8

Independent samples t-Test (Post-test)

\begin{tabular}{|c|c|c|c|c|c|c|c|c|}
\hline & & \multicolumn{2}{|c|}{$\begin{array}{l}\text { Levene's Test for Equality } \\
\text { of Variances }\end{array}$} & \multicolumn{5}{|c|}{ t-test for Equality of Means } \\
\hline & & $\mathrm{F}$ & Sig. & $\mathrm{t}$ & df & $\begin{array}{l}\text { Sig. (2- } \\
\text { tailed) }\end{array}$ & $\begin{array}{l}\text { Mean } \\
\text { Difference }\end{array}$ & $\begin{array}{l}\text { Std. Error } \\
\text { Difference }\end{array}$ \\
\hline $\begin{array}{l}\text { post- } \\
\text { test }\end{array}$ & $\begin{array}{l}\text { Equal } \\
\text { variances } \\
\text { assumed }\end{array}$ & .375 & .544 & 2.495 & 38 & .017 & 9.50000 & 3.80809 \\
\hline
\end{tabular}

The results of T-test comparison between the mean scores of two groups demonstrated that authentic videos have a tremendous impact on the EFL students' prosodic ability. Statistically, independent samples t-test was applied to compute scientifically the amount of difference between the performances of both groups on the post-test and to determine objectively if there was a significant difference between both groups. The independent samples t-test was calculated with the T. Value of 2.495 and the P. value equalling 0.017. These findings demonstrate that a significant difference is observed. Hence, these statistical outcomes confirm that the hypothesis of the study which states, "Using authentic videos do not have a significant impact on the prosodic ability of EFL learners" is rejected.

Table 9

Descriptive statistics (pre vs. post-tests of experimental and control groups)

\begin{tabular}{llllll}
\hline & & Mean & N & Std. Deviation & Std. Error Mean \\
\hline Pair 1 & Exp. Post-test & 70.6000 & 20 & 12.78321 & 2.85841 \\
\cline { 2 - 6 } & Exp. Pre-test & 58.2000 & 20 & 6.46936 & 1.44659 \\
\hline \multirow{2}{*}{ Pair 2 } & Cont. Post-test & 61.1000 & 20 & 11.25260 & 2.51616 \\
\cline { 2 - 6 } & Cont. Pre-test & 59.8500 & 20 & 13.21194 & 2.95428 \\
\hline
\end{tabular}


Table 10

Paired samples statistics (pre-test vs. post-test)

\begin{tabular}{|c|c|c|c|c|c|c|c|c|c|}
\hline & & \multicolumn{5}{|c|}{ Paired Differences } & \multirow[t]{3}{*}{$\mathrm{t}$} & \multirow[t]{3}{*}{$\mathrm{df}$} & \multirow{3}{*}{$\begin{array}{l}\text { Sig. (2- } \\
\text { tailed) }\end{array}$} \\
\hline & & \multirow[t]{2}{*}{ Mean } & \multirow[t]{2}{*}{$\begin{array}{l}\text { Std. } \\
\text { Deviation }\end{array}$} & \multirow[t]{2}{*}{$\begin{array}{l}\text { Std. } \\
\text { Error } \\
\text { Mean }\end{array}$} & \multicolumn{2}{|c|}{$\begin{array}{l}\text { 95\% Confidence } \\
\text { Interval of the } \\
\text { Difference }\end{array}$} & & & \\
\hline & & & & & Lower & Upper & & & \\
\hline Pair 1 & $\begin{array}{l}\text { Exp. Posttest- } \\
\text { Exp. Pretest }\end{array}$ & 12.400 & 9.610 & 2.148 & 7.902 & 16.897 & 5.770 & 19 & .000 \\
\hline Pair 2 & $\begin{array}{l}\text { Cont. } \\
\text { Posttest- } \\
\text { Cont. Pre-test }\end{array}$ & 1.250 & 5.485 & 1.226 & -1.317 & 3.817 & 1.019 & 19 & .321 \\
\hline
\end{tabular}

Table 10 indicates that the sig. for control group at df 19 is (.321) which is higher than (0.05); therefore, the difference between the post-test and pre-test of the control group is not significant. But, since the sig. (.000) for experimental group is less than $0.05(\mathrm{p}<0.05)$; the difference between the post-test and pre-test of the experimental group is significant. The treatment resulted in significant difference in pre and post-tests of participants in the experimental group.

\section{DISCUSSION}

In this section the research question "Do authentic videos have any significant effect on Iranian intermediate EFL learners' prosodic ability?" is replied according to the results obtained in the tables above. After collecting the data, the researcher used independent and paired samples t-test to analyse them to find out the effectiveness of authentic videos on the students' prosodic ability. The results indicated that performance of the control and experimental groups in pre-test was almost the same. However, the results obtained from their post-test showed the experimental group significantly performed better than the control groups. In fact, those students who received the treatmentauthentic videos- did better and had better scores. It is concluded that using authentic videos had positive impacts on Iranian EFL learners' prosodic ability.

Generally speaking, after checking the impact of authentic videos on the learners' supra segmental ability, the outcomes of the research have demonstrated that there is much improvement in the experimental group's prosodic ability. Therefore, the hypothesis of the study, "Authentic videos do not have a significant influence on EFL learner's prosodic ability" is rejected.

The findings of the study revealed that the mean of scores of the experimental group in terms of prosodic features of language on the post-test was much higher than their performance on the pre-test. Also, the outcomes of the research indicated that in every prosodic component of language a large gap exists between the mean scores of participants on the post-test when compared with that on the pre-test. In addition, the consequences of the study demonstrated that much difference is clearly observed among the mean of scores of all members in the experimental group on the pre-test comparing with that of the post-test. Ultimately, the researcher understood that there was considerably enhancement in students' prosodic ability on the post-test that was carried out after 12 session's experiment of being taught authentic videos. In this situation, EFL learners obtained the prosodic aspects of language effortlessly and appropriately. These 
recordings were offered in various circumstances and in diverse rapidity from the mouths of native speakers who are of various jobs, ages, sexes, settings of speaking and educational levels and social statuses because language with its prosody differs from one context of discourse to another. The consequences of the investigation additionally uncovered that almost all students have progressed their general prosodic ability, although there was minor deficiencies in the performance of three students. This is hard to clarify, however as teachers know, a class is compound of a diversity of learners, some with supreme study practices and others without beneficial ones, and some students actually are not interested. The numbers of these instances of low proficiency were small. It was two out of twenty. Roughly, $10 \%$ of the students demonstrated no progressions and $90 \%$ enhanced their prosodic ability. The most astounding advancement was in students' utilization of stress, and pronunciation. Nonetheless, the least advance was in articulation of speech sounds, particularly in pronouncing those consonants and vowels that do not stand in the students' mother tongue. Students who got the highest total score on the post-test did not indicated much development intonation, pause and juncture. This might be because of the impact of the student's mother tongue. The team of examiners additionally mentioned that hesitation and stress have to some degree influenced students' execution. Their hesitations sometimes made a large number of pauses and junctures than anticipated. Furthermore, this study also confirmed the results of Al-Domi (2017) who checked the effect of utilizing authentic videos on teaching center and community service students' prosodic ability and motivation. He reached to this finding using authentic videos in teaching and learning English has a positive effect on the prosodic ability and motivation domains.

Generally, the results of the current study are congruent with other researches which have corroborated the fruitful influence of incorporating audio-visual materials to improve the prosodic ability of a foreign language (Garza, 1991; Markham, 2003). To put it in a nutshell, the findings demonstrates that, presenting students to authentic visual materials will result to a profound and fathomless processing of input and append the intake correspondingly.

\section{CONCLUSION}

The results revealed that Iranian EFL learners can benefit from authentic videos. The TTest findings showed that there were significant differences between the mean scores for both experimental and control groups in favour of the first. Differences between these two groups may be ascribed to various teaching methods; the experimental group was presented to authentic videos technology and the control to traditional teaching. The experimental group students significantly developed their prosodic ability via utilizing authentic videos technology. They performed significantly in the post-test. As the result, the hypothesis which states "There are no statistically significant differences between the mean scores of the experimental groups students' mastery of the prosodic features of language" at $\alpha<0.05$ is not confirmed. In light of the findings of the present examination, it can be concluded that the using authentic videos in teaching and learning can produce positive results because they could absorb students in learning English. The positive influences of utilizing authentic videos became evident after the treatment. 
Therefore, it can be mention that receiving instruction through using authentic videos can facilitate English learning. Moreover, based on the experts' analysis of the prosodic ability of experimental group, the researcher realized that exposing students to authentic recording texts and dialogues which taken from real context will enhance their prosodic ability in terms of perception and production of speech sounds and lexicons. Thus, the discoveries of the present investigation demonstrate that regular presentation to authentic videos will enable students in figuring out how to grasp English language prosodic features successfully. It can be claimed that if English students are presented to authentic materials, their prosodic ability can considerably be progressed. Educators can request their students to watch English TV programs as repeatedly as possible. Moreover, it is possible for English institutions to give chances to their students to watch unique videos together in the class and appreciate its advantages too.

\section{REFERENCES}

Abdolmanafi-Rokni, S. J. (2013). The effect of listening to audio stories on pronunciation of EFL learners. MJAL 5(2), 69-85.

Abdullah, A. (2011). Using Video Recordings and Reflection Papers in Enhancing Communicative and Paralinguistic Skills in Higher Education Contexts Cairo University (Egypt).

Al-Domi, I. M. B. (2017). The effect of using authentic videos on training center and community service students' prosodic competence and motivation. Arab World English Journal, 8 (4), 85-100.

Bataineh, A., \& Al-Qadi, N. (2014). The effect of using authentic videos on English major students' prosodic competence. Journal of Education and Practice, 5(3), 157172.

Braithwaite, M. (2008). Sounds right. New Plymouth, New Zealand: Curriculum Concepts.

Brown, D. (2000). Principles of language learning and teaching. White Plains, NY: Addison Wesley Long-man.

Corder, S. (1983). Introduction to applied linguistics. England: Penguin Books.

Cruz- Ferreira, M. (1987). Non-native interpretive strategies for intonational meaning: An experimental study. In A. James \& J. Leather (eds.), Sound patterns in second language acquisition (pp. 103-120). Dordrecht: Foris.

Crystal, D. (1987). The Cambridge encyclopedia of language. Cambridge: Cambridge University Press.

Dechert, H. W., \& Raupach. M. (1987). Prosodic patterns of proceduralized speech in second and first language narratives. In A. James \& J. Leather (eds.). Sound patterns in second language acquisition (pp. 81-102). Dordrecht: Foris.

EbruAtak, D. (2014). Task-based video use for the improvement of English stress and intonation. Journal of Educational and Social Research MCSER Publishing, Rome-Italy. 
Eskenazi M. (1999). Using automatic speech processing for foreign Language pronunciation tutoring: Some issues and a prototype. Language Learning \& Technology, 2(2), pp. 62-76.

Garza, T. J. (1991). Evaluating the use of captioned video materials in advanced foreign language learning. Foreign Language Annals, 24(3) 239-258.

Hardison, D. (2004). Generalization of computer-assisted prosody training: Quantitative and qualitative findings. Language Learning and Technology, 8(1), 34-52.

Hirata, Y. (2004). Computer-assisted pronunciation training for native English speakers learning Japanese pitch and duration contrasts. Computer Assisted Language Learning, 17(3-4), 357-376.

Hiser, N., \& Kopecky, A. (2009). American speech sounds. Portland, OR: American Speech sounds.

Khaghaninejad, M. S., \& Maleki, A. (2015). The effect of explicit pronunciation instruction

on listening comprehension: evidence from Iranian English learners. Theory and Practice in Language Studies, 5(6), 1249-1256.

Lepetit, D. (1989). Cross-linguistic influence in intonation: French/Japanese and French/ English. Language Learning 39 (3), pp. 397-413.

Markham, P. L (2003). Captioned television videotapes: effects of visual support on second language comprehension. Journal of Educational Technology Systems, 21(3) 183-191.

Morley, J. (1996). Rapid review of vowel and prosodic contexts. Ann Arbor: University of Michigan Press.

O'Brien, M. (2006). Teaching pronunciation and intonation with computer technology. In L. Ducate \& N. Arnold (Eds.), Calling on CALL: From theory and research to new directions in foreign language teaching (CALICO Monograph Series, Vol. 5, pp. 127148). San Marcos, TX: CALICO

Pennington, C., \& Ellis, N. C. (2000). Cantonese speakers' memory for English sentences with prosodic cues. Modern language journal, 84 (3), pp. 372-389.

Peter, J. (2002). How to do it to do it right? Is near native-like pronunciation teachable/ learnable? In E. WaniekKlimczak and P. Melia (Eds), Accents and speech in teaching English phonetics and phonology, Frankfurt and Main: Peter Lang.

Stempell, G. (1981). Content analysis. In Sempell III and B. H. Westley (Eds). Research methods in mass communication, pp. 111-126, Englewood Cliffs: Prentice Hall Inc.

Tarone, E. (2005). Speaking in a second language. In E. Hinkel (Ed.), Handbook of research in second language learning and teaching, pp. 485-502, Mahwah, NJ: Lawrence Erlbaum.

Varasarin, P. (2009). An action research study of pronunciation training, language learning strategies and speaking confidence (Ph.D. Dissertation).Victoria University. 